\title{
The Effect DM Diet -Adherence and Medication Intake on Blood Glucose Level of DM Patients at Cempaka Putih District Health Center, Central Jakarta
}

\author{
Nur Asniati Djaali ${ }^{1}$, Rani Pertiwi ${ }^{2}$, Hany Lestary ${ }^{3}$, Inggit Meliana Anggarini ${ }^{4}$, Suhermi ${ }^{5}$ \\ \{nurdjaali@gmail.com ${ }^{1}$, ranipertiwi58t@gmail.com ${ }^{2}$, \\ lestaryheny@yahoo.com ${ }^{3}$, inggit.anggarini@gmail.com ${ }^{4}$, esuhermi@yahoo.co.id ${ }^{5}$ \} \\ Faculty of Health, Mohammad Husni Thamrin University, Jakarta, Indonesia ${ }^{1,3,4,5}$ \\ Research and Development of Health Ministry of Indonesia, Jakarta, Indonesia ${ }^{2}$
}

\begin{abstract}
Type II Diabetes Mellitus (DM) is a metabolic disorder that is currently a major health problem in Indonesia because it has a fairly high prevalence and increases every year. The purpose of this study was to know the effect of DM diet-adherence and medication intake on changes in blood glucose levels in patients with Type II DM at the Cempaka Putih District Health Center in Central Jakarta, Indonesia. This study was a quantitative research with cross-sectional design. This study involved 45 respondents who participated in the PPDM Program in 2018 at that place. Data were analyzed by statistical tests with categorical data. This study showed that $53.3 \%$ of respondents had uncontrolled blood glucose levels, of which $75 \%$ were not compliant in the DM diet, and $54.2 \%$ were not regular in their medication intake behavior. The results of the Chi-Square Test showed that DM diet-adherence and medication intake affected the blood glucose levels of DM patients with odd ratio was 4.8 and 7.1, respectively. To control blood glucose levels, it was recommended that DM patients maintain dietary compliance and medication intake by following a balanced DM diet recommendation from nutrition workers. With controlled blood glucose levels, various complications of the disease can be prevented, and the quality of life of DM patients can increase.
\end{abstract}

Keywords: Type II Diabetes Mellitus, Blood Glucose Level, DM Diet-adherence, medication intake.

\section{Introduction}

Diabetes mellitus or commonly called DM, is a group of metabolic diseases with characteristics of hyperglycemia due to abnormal insulin secretion, insulin action, or both. DM is a degenerative disease that contributes to the cause of death in several countries in the world. Thirty-eight million (68\%) out of 56 million deaths in the world in 2012 were caused by degenerative diseases. DM becomes a serious health problem due to its high prevalence, increased morbidity, and the high impact on costs [1].

The prevalence of people with Diabetes Mellitus in Indonesia tends to increase, from 5.7\% in 2007 to $6.9 \%$ in 2013, and increased again to $8.5 \%$ in 2018 [2]. In 2015 Indonesia was in the seventh position with 10 million sufferers and was expected to increase in 2040, as many as 16.2 million sufferers, meaning that there will be an increase in a number of sufferers as 
much as $56.2 \%$ from 2015 to 2040 . Indonesia was also the third country where the number of people with impaired glucose tolerance (20-79 years) in 2015 was 29 million people [3].

The 2013 Indonesia Basic Health Research (Riskesdas) interviewed to calculate the proportion of diabetes mellitus at the age of 15 years and above. The results showed $6.9 \%$ of $176,689,336$ residents, or approximately 12,191,564 residents suffer from DM. Those who have been diagnosed are $30.4 \%$ or approximately $3,706,236$ residents, and those who have not been diagnosed are $69.4 \%$ or approximately $8,485,329$ residents [4].

The proportion of Diabetes Mellitus diagnosed by doctors in the Special Capital Region of Jakarta Province, which was based on interviews, shows that the highest was in the 55-64 year age group of $(11.7 \%)$. While the lowest was in the $25-34$ year age group, which was $(0.1 \%)$. The highest proportion of diabetes mellitus according to the district/city of Special Capital Region of Jakarta Province was in South Jakarta (3.1\%), followed by East Jakarta (3.0\%), Seribu Islands (2.5\%) and Central Jakarta (2.2\%). Meanwhile, the lowest proportion of Diabetes Mellitus was in West Jakarta (1.7\%), followed by North Jakarta (1.9\%) [4].

According to data obtained at the Cempaka Putih District Health Center, Central Jakarta, in 2017, the population of the case of Diabetes Mellitus was 798 people. There were 464 women $(58.1 \%)$ and 334 men $(41.8 \%)$. The population of DM cases in February-April 2018 was 156 people. There were 84 women $(53.8 \%)$ and 72 men $(46.1 \%)$. The majority of those who routinely seek treatment at the Puskesmas were people with Type II Diabetes Mellitus $[5]$.

Type II Diabetes Mellitus is a metabolic disorder characterized by high blood sugar levels due to insulin resistance and insulin deficiency (impaired insulin secretion). Type II DM is incurable; however, can be controlled by controlling the blood glucose level. Blood glucose can be said to be controlled if fasting blood glucose levels of type 2 DM sufferers $<126 \mathrm{mg} / \mathrm{dl}$. If people with type 2 diabetes do not control blood sugar levels properly, then blood sugar levels can be unstable; increases and decreases, which can lead to complications [6].

PPDM (Management of Type II Diabetes Mellitus) was a program from Polaris conducted at the Cempaka Putih District Health Center, Central Jakarta. The activities carried out are physical exercise such as diabetes exercise, providing counseling/education related to Diabetes Mellitus, and routine blood glucose checkups every month. The goal of monthly blood sugar checkups was to determine the management of blood glucose level of people with Type II DM [7].

Compliance with the DM diet is one of the factors that affect blood glucose levels in someone who has suffered from DM. Dietary compliance is one of the keys to success in managing DM disease. This is because meal planning is one of the 4 main pillars of managing DM. Dietary compliance is a big problem that occurs in people with DM; diet is the most difficult habit to change, and the lowest level of compliance in self-management of a DM patient [8].

Also, the intake of medication is also the main factor that must be considered in a DM patient. The working mechanism of oral hypoglycemic drugs generally stimulates pancreatic beta cells to secrete insulin or reduce glucose absorption in the intestine, thereby reducing glucose levels in the blood. Meal planning is still the main treatment; however if meal alongside physical exercise turns out to be a failure, it is necessary to add oral medication. Oral hypoglycemic drugs are given so that Diabetes Mellitus can be controlled properly [9].

Based on some of the above, a study was conducted to see the effect of DM diet adherence and intake of medication on blood sugar levels in DM patients who were participants in the PPDM Program. It was expected that the results of this study could provide recommendations 
regarding preventive measures to control blood glucose levels in people with Diabetes Mellitus.

\section{Method}

This study was a quantitative study with a crossectional approach. The study was conducted in the Cempaka Putih District Health Center in Central Jakarta in April-June 2018. It involved 45 people with DM who participated in the DM management program at the Cempaka Putih Health Center using incidental sampling.

Data collection was done through questionnaires and direct interviews with respondents. The questionnaire was developed by researchers to obtain information about the characteristics of respondents (gender, age, education level, duration of diabetes mellitus, and family support), and the main independent variables were adherence to the DM diet and intake of medication. Whereas for the dependent variable, blood glucose levels were examined at the Primary Health Center using glucometers carried out by health workers. The results of the examination of blood glucose levels were taken by looking at the medical records of the respondents in the health center.

To see an overview of the main characteristics and independent variables, univariate analysis of categorical data was carried out by presenting numbers and percentages. Furthermore, bivariate analysis was performed using the chi-square test to examine the relationship between adherence to the DM diet and regularity of taking the medication with blood sugar levels.

\section{Result}

Table 1. shows an overview of the blood sugar levels of respondents based on gender, age, education level, duration of suffering from diabetes, and family support. Most of the respondents were women, and $51.6 \%$ of them had uncontrolled blood glucose levels. Uncontrolled blood sugar was dominated by respondents with age $<64$ years $(57.9 \%)$, a higher education level (graduating college) $(80 \%)$, suffering from DM more than 5 years $(71 \%)$, and not receiving family support for treatment $(62.5 \%)$.

Table 1. Overview of Blood Glucose Levels Based on Characteristics of Respondents (Gender, Age, Education Level, Duration of DM, and Family Support)

\begin{tabular}{|c|c|c|c|c|c|c|}
\hline \multirow{3}{*}{ Variable } & \multicolumn{6}{|c|}{ Blood Glucose Level } \\
\hline & \multicolumn{2}{|c|}{ Uncontrolled } & \multicolumn{2}{|c|}{ Controlled } & \multicolumn{2}{|c|}{ Total } \\
\hline & $\mathbf{n}$ & $\%$ & $\mathbf{n}$ & $\%$ & $\mathbf{n}$ & $\%$ \\
\hline \multicolumn{7}{|l|}{ Gender } \\
\hline Female & 16 & 51,6 & 15 & 48,4 & 31 & 100,0 \\
\hline Male & 8 & 57,1 & 6 & 42,9 & 14 & 100,0 \\
\hline \multicolumn{7}{|l|}{ Age of Respondents } \\
\hline$\geq 64$ years old & 13 & 50,0 & 13 & 50,0 & 26 & 100,0 \\
\hline$<64$ years old & 11 & 57,9 & 8 & 42,1 & 19 & 100,0 \\
\hline
\end{tabular}


Educational Level

Uneducated

Elementary School Graduates

2

66,7

40,0

33,3

100,0

Junior High School Graduates

43,8

60,0

100,0

High School Graduates

56,3

56,3

100,0

Higher Education Graduates

80,0

43,8

100,0

4

20,0

100,0

Duration of suffering from DM

$\geq 5$ years
$<5$ years
ily Support

22

71,0

29,0

100,0

2

14,3

85,7

100,0

Family Support

$\begin{array}{lllllll}\text { No } & 10 & 62,5 & 6 & 37,5 & 16 & 100,0 \\ \text { Yes } & 14 & 48,3 & 15 & 51,7 & 29 & 100,0\end{array}$

Table 2 is the result of bivariate analysis using the chi-square test to see the effect of DM diet adherence and medication intake on blood glucose levels of Type II DM patients. The results of the analysis showed that $69.2 \%$ of respondents who had uncontrolled blood sugar levels were not adherent to the DM diet, and $81.3 \%$ were not regular in taking medication.

Table 2. Results of Analysis of the Relationship between Blood Glucose Level with DM Diet Adherence and Medication Intake

Furthermore, the results of the chi-square analysis showed that the blood glucose level of the respondents was influenced by adherence in the $\mathrm{DM} \operatorname{diet}(\mathrm{Pv}=0.028$; $\mathrm{OR}=4.8)$ and

\begin{tabular}{|c|c|c|c|c|c|c|c|c|c|c|}
\hline \multirow{3}{*}{ Variables } & \multicolumn{6}{|c|}{ Blood Glucose Level } & \multirow{3}{*}{$\mathbf{P}_{\text {value }}$} & \multirow{3}{*}{ OR } & \multicolumn{2}{|c|}{$95 \% \mathrm{CI}$} \\
\hline & \multicolumn{2}{|c|}{ UnControlled } & \multicolumn{2}{|c|}{ Controlled } & \multicolumn{2}{|c|}{ Total } & & & \multirow{2}{*}{ lower } & \multirow{2}{*}{ upper } \\
\hline & $\mathbf{n}$ & $\%$ & $\mathbf{n}$ & $\%$ & $\mathbf{n}$ & $\%$ & & & & \\
\hline \multicolumn{11}{|l|}{$\begin{array}{l}\text { DM Diet } \\
\text { Adherence }\end{array}$} \\
\hline Not adhere & 18 & 69,2 & 8 & 30,8 & 26 & 100,0 & \multirow{2}{*}{0,028} & \multirow{2}{*}{4,875} & \multirow{2}{*}{1,360} & \multirow{2}{*}{17,472} \\
\hline Adhere & 6 & 31,6 & 13 & 68,4 & 19 & 100,0 & & & & \\
\hline
\end{tabular}

Medication

intake

\begin{tabular}{lcccccccccc} 
Not regular & 13 & 81,3 & 3 & 18,8 & 16 & 100,0 & & & \\
Regular & 11 & 37,9 & 18 & 62,1 & 29 & 100,0 & & & & \\
\hline
\end{tabular}

regularity in taking medication $(\mathrm{Pv}=0.013$; OR $=7.1)$. Someone who does not adhere to a DM diet has 4.8 times chance to have uncontrolled blood sugar levels compared to those who are adherent to the DM diet. Furthermore, someone who is not regular in taking medication has 7.1 times chance to have uncontrolled blood sugar levels compared to those who are regularly in taking medication 


\section{Discussion}

\subsection{Blood glucose levels}

Blood glucose level is the amount of glucose present in the blood and is the result of carbohydrate metabolism from food. Controlling good and optimal blood glucose levels is needed to be able to prevent chronic complications. To express controlled blood glucose levels, it does not only depend on the loss of symptoms of diabetes mellitus alone but must be examined by blood glucose levels [10]. The results of an examination of blood sugar levels found that from 45 respondents, there were 53.3\% who had uncontrolled blood sugar levels and $46.7 \%$ who had controlled blood glucose levels. The research conducted by Fahmiyah (2016) also showed a similar result, from 50 patients in the Diabetes Policlinic of Dr. Soetomo Hospital, there were $66 \%$ who had uncontrolled blood glucose level and $34 \%$ who had controlled blood sugar levels [10].

\subsection{Characteristics of respondents}

Gender is one of the factors associated with the occurrence of Diabetes Mellitus. According to Imam Suharto (2005), Diabetes Mellitus can be found mostly in women compared to men. This is because women have higher LDL or bad cholesterol triglyceride levels compare to men, and there are differences in activities and daily lifestyles. Also, the lipid levels (blood fat) in women tend to increase more compared to men [11]. Thus, women have a higher tendency to experience increased blood glucose levels compare to men. Research conducted by Rudi and Kwureh (2016), stated that there was a significant relationship between gender and blood sugar levels in laboratory service users in $M$. Djoen Sintang Hospital in 2016. Likewise in the study conducted by Isworo (2008) on Type II Diabetes Mellitus patients in Sragen General Hospital that women had 19.74 times higher risk to develop poor blood glucose levels compared to male [13].

Regarding the age of type II DM patients, it usually occurs after the age of 30 years and increasingly occur after the age of 40 years, then continue to increase in older age. Elderly people who experience impaired glucose tolerance reach 50-92\%. Age is very closely related to the increase in blood glucose levels; thus while the age increases, the prevalence of diabetes and impaired glucose tolerance increases as well. However, age is not the main factor of uncontrolled blood glucose levels. There are other possible factors that are more related to blood glucose levels, such as lifestyle or behavior. Behavior can be seen from the level of adherence in managing DM disease that is from physical activity/diabetes exercise, participate in counseling, adherence to medication and DM diet and family support can provide support related to controlling blood glucose levels [14],[15].

Education is also associated with Diabetes Mellitus, even though education is not in line with one's behavior. Education is an effort of persuasion or learning to the community, so that people have the desire to take actions to maintain or overcome problems, and improve their health [16]. Education has a high relation to patient behavior to maintain and improve their health. Education for patients with Diabetes Mellitus is related to the behavior of patients in controlling their blood glucose levels to remain within normal limits. The results of this study indicate that uncontrolled blood glucose levels are mostly found in higher education graduates. This reflects that blood glucose levels of an individual can be uncontrolled does not depend on the last education level but there are other factors that can trigger uncontrolled blood sugar levels such as lifestyle, namely the level of adherence to taking medication recommended by the doctor, adherence to DM diet and physical exercise. 
The duration of patients suffering from Diabetes Mellitus affects the tolerance of cells and tissue to glucose in the blood, the long suffering from uncontrolled diabetes, the lower the tolerance to glucose [17]. The number of respondents in this study who suffer from DM for $\geq$ 5 years is higher compare to $<5$ years. This is probably caused by an age factor where the average age of PPDM participants is 64 years. Age is very closely related to the increase in blood glucose levels; thus while the age increases, the prevalence of diabetes and impaired glucose tolerance is higher. While the age increases, the organ function, namely the brain function that is associated with memory, may also decrease. The memory affects patients in carrying out adherence to control blood glucose level. Another possibility may also be caused by psychological factors where if someone suffers a disease for a long time, the perception to recover from the disease will decrease. Thus according to the theory above, which says that the long suffering from uncontrolled diabetes, the lower the tolerance to glucose in the blood [18].

Related to family support, Friedman, Bowden \& Jones (2010) stated that family support is attitude, action, and family acceptance of its members. Family members are seen as part of the environment of the family. Families are seen as supportive people who are always ready to assist if needed. Hensarling's theory (2009) stated that family support is the most powerful indicator to have a positive impact on self-care in DM patients. Families who are caregivers can provide support to family members with chronic diseases [19].

\subsection{DM diet Adherence}

The of the Chi-Square statistical test obtained a p-value of 0.028 , which means that adherence to the DM diet significantly affects blood sugar levels. The OR of 4.8 means that someone who is not obedient in carrying out a DM diet has 4.8 times more risk to develop uncontrolled blood sugar levels compared to those who are obedient in doing the DM diet. This research is in line with the research conducted by Hapsari (2017), which stated that there was a significant relationship between diet compliance with blood glucose levels [20]. Then the study conducted by Eva Mona (2012) on patients with Diabetes Mellitus in Tugurejo Hospital in Semarang, revealed similar result that there was a relationship between adherence to diet with blood glucose levels, where the results of this study stated that blood glucose levels were more controlled (73.5\%) in DM patients who adhere to the diet compared to those who do not adhere [21].

According to Niven (2002), adherence is the extent to which patient behavior is by the provisions given by health professionals. Dietary compliance is one of the keys to success in managing DM disease. Meal planning is one of the four main pillars of managing DM. Dietary adherence is based on 3J aspects, namely adhering to the schedule, type, and amount [22].

One's adherence to the DM diet can be influenced by several factors, one of which is knowledge. A person's lack of knowledge results in a lack of understanding of information regarding dietary recommendations and low education levels. Also, it can also be caused by age; when the age is increasing, there will be a decline in the function of organs, namely brain function that is associated with memory. So that with increasing age in DM patients, the ability to plan daily food will also decrease. Furthermore, family support also affects the eating habits of the respondents; thus, it may affect their blood glucose levels. 


\subsection{Medicine Intake}

Based on the results of the Chi-Square statistical test, the P-value of 0.013 was obtained, which means that there was a significant relationship between medicine intake and blood glucose levels. The OR value is 7.1, which means that someone who is nor regular in taking medication has a 7.1 times more chance to develop uncontrolled blood sugar levels compared to those who are regularly taking medication.

The results of this study are in line with the research conducted by Trisnawati (2013) on Diabetes Mellitus Patients, which stated that there is a relationship between the level of adherence on taking medication and blood glucose levels. Intake of taking medicine is very closely related to one's knowledge and attitude towards health. Someone who has a positive attitude towards healthy living will tend to do good behavior towards a healthier life compared to someone who has a negative attitude. A person's negative attitude will lead towards something that he thinks is not beneficial to him [23].

The level of one's knowledge also greatly influences it in behaving. Notoadmodjo (2010) stated that one of the factors that determine a person's health behavior is the level of knowledge [16]. According to Soewondo (2005), with increasing knowledge, the DM patients able to manage the disease so that the patient's health condition becomes better. Taking medication regularly is the main factor in managing DM disease. Medicine intake is an inseparable part of the management of DM because by taking medication regularly and according to the doctor's instructions, good control of blood glucose levels can be achieved, thus ultimately reduces the risk of chronic diabetes complications [24].

\section{Conclusion}

Adherence to DM diet and regularly taking medication are the two main factors that are important to control blood glucose levels in DM patients. Someone who has been diagnosed with DM will have the potential for developing chronic complications and developing other comorbidities. Therefore, routine control of blood glucose levels must be done, and also paying attention to diet and regularly taking the appropriate medication based on the instruction given by the doctor. Non-adherence in the DM diet will result in 4.8 times more risk s for uncontrolled blood glucose. While irregularities in the intake of medication will result in 7.1 times more risk for uncontrolled blood glucose levels.

Focusing on counseling and education will help in increasing knowledge and awareness for DM patients in adhering to the DM diet and taking medication according to the doctor's instructions. Increased creativity in making poster media and leaflets about DM diet knowledge which includes 3J "Meal Schedule, Meal Amount, and Types of Meal" will be very necessary for the PPDM program at the Primary Health Care.

To control blood glucose levels, it was recommended that DM patients maintain dietary compliance and medication intake by following a balanced DM diet recommendation from nutrition workers. With controlled blood glucose levels, various complications of the disease can be prevented, and the quality of life of DM patients can increase. 


\section{References}

[1] World Health Organization.:Global Report on Diabetes (Geneva: WHO).pp.23-40 (2016)

[2] Report of Basic Health Research (Jakarta: Badan Penelitian dan Pengembangan Kesehatan RI).(2018)

[3] International Diabetes Federation.: IDF Diabetes Atlas (Brussels: IDF).pp.1-10 (2015)

[4] Report of Basic Health Research:(Jakarta: Badan Penelitian dan Pengembangan Kesehatan RI).(2013)

[5] Dinas Kesehatan.:Profil Puskesmas Kecamatan Cempaka Putih (Jakarta: Dinas Kesehatan Jakarta Pusat).pp.12-20 (2017)

[6] PERKENI.:Pengelolaan dan Pencegahan Diabetes Melitus Tipe 2 di Indonesia (Jakarta: PB PERKENI).pp.1-34 (2015)

[7] BPJS.:Panduan Praktis Prolanis (Program Pengelolaan Penyakit Kronis) (Jakarta: BPJS Kesehatan).pp.23-40 (2014)

[8] Tovar, E G.: Relationship Between Psychosocial Factor and Adherence to Diet and Exercise in Adult With Type 2 Diabetes: A Test Of a Theoretical Model (The University of Texas Medical Branch).pp.2-14 (2007)

[9] Soegondo, S.: Farmakologi pada Pengendalian Glikemia Diabetes Mellitus Tipe 2. Buku Ajar Ilmu Penyakit Dalam (3rd Ed.) (Jakarta: Pusat Penerbit Departemen Penyakit Dalam FKUI).pp. 18821885. (2006)

[10] Soewondo, S \& Soewondo, P.; Penatalaksanaan Diabetes Melitus Terpadu: Sebagai Panduan Penalatalaksanaan Diabetes Melitus Bagi Dokter Maupun Edukator (Jakarta: FKUI).pp. 3-7 (2007)

[11] Fahmiyah, Indah dan Silatra, I Nyoman.: Faktor yang Mempengaruhi Kadar Gula Darah Puasa Pasien Diabetes Melitus Tipe 2 di Poli Diabetes RSUD Dr. Soetomo Surabaya Menggunakan Regresi Probit Binner Journal Sains dan Seni Vol.5.pp.2337-3520. (2016)

[12] Imam Soeharto.: Serangan Jantung dan Stroke Hubungannya Dengan Lemak dan Kolesterol (Jakarta: Gramedia Pustaka Utama)pp.40-50 (2005)

[13] Isworo, Atyant.: Hubungan Depresi Dan Dukungan Keluarga Terhadap Kadar Gula Darah Pada Pasien Diabetes Mellitus Tipe 2 di RSUD SRAGEN (Tesis: Program Pascasarjana Fakultas Ilmu Keperawatan Universitas Indonesia Depok).pp.15-29 (2008)

[14] Masruroh, Eny.; Hubungan Umur Dan Status Gizi Dengan Kadar Gula Darah Penderita Diabetes Melitus Tipe 2. Jurnal Ilmu Kesehatan. Vol 6. Pp.1-9.(2018)

[15] Mikus.: Glycaemic control is improved by 7 days of aerobic exercise training in patients with type 2 diabetes Diabetelogia Vol.55.pp1417-1423.(2012)

[16] Notoatmodjo, Soekidjo.:Pendidikan dan Perilaku Kesehatan (Jakarta: Rineka Cipta).pp.3037.(2003)

[17] Budianto, Apri.: Gambaran Perubahan Kadar Glukosa Darah Pada Pasien Diabetes Melitus Tipe 2 yang Melakukan Senam Diabetes di PERSADIA Kota Depok (Tesis: Program S2 Ilmu Keperawatan Medikal Bedah Fakultas Ilmu Keperawatan Universitas Indonesia Depok).pp.20-30. (2014)

[18] Berkat.:Faktor-Faktor Yang Berhubungan Dengan Kadar Gula Darah Pada Penderita Diabetes Melitus Tipe 2 Di RSUD K.R.M.T Wongsonegoro Semarang Jurnal Kesehatan Masyarakat .Vol. 6 .pp.2356-3346.(2018)

[19] Hensarling, J.:Development and psychometric testing of Henserling's diabetes family support scale, a dissertation Degree of Doctor of Philosophy in the Graduate School of the Texa's Women's University.pp.23-40.(2009)

[20] Hapsari.:Pengaruh Penyuluhan tentang Pola Makan Pada Penderita Diabetes Dengan Dan Tanpa Komplikasi di Kecamatan Getasan Jurnal Ilmu Kesehatan Vol 5.pp.1-19.(2017) 
[21] Mona, Eva.:Hubungan Frekuensi Pemberian Konsultasi Gizi dengan Kepatuhan Diit Serta Kadar Gula Darah Penderita Diabetes Melitus Tipe 2 Rawat Jalan di RS Tugurejo Semarang Jurnal Kesehatan.Vol 1.pp.1-8.(2012)

[22] Niven, Neil.Psikologi Kesehatan dan Pengantar untuk Perawat dan Profesional Kesehatan Lain (Jakarta: EGC).pp.23-40.(2012)

[23] Trisnawati.;Faktor Risiko Kejadian Diabetes Melitus Tipe 2 Di Puskesmas Kecamatan Cengkareng Jakarta Barat Jurnal Ilmiah Kesehatan Vol 5.pp.3-9. (2013)

[24] Soewondo, P.Pemantauan Pengendalian Diabetes Melitus (Jakarta: Balai Penerbit FK UI).pp.153159. (2005) 